\title{
Diversity of Airway Epithelial Cell Targets for In Vivo Recombinant Adenovirus-mediated Gene Transfer
}

\author{
Andrea Mastrangeli, ${ }^{*}$ Claire Danel, ${ }^{*}$ Melissa A. Rosenfeld,“ Leslie Stratford-Perricaudet, ${ }^{\star}$ Michel Perricaudet, \\ Andrea Pavirani," Jean-Pierre Lecocq," and Ronald G. Crystal* \\ *Pulmonary Branch, National Heart, Lung, and Blood Institute, National Institutes of Health, Bethesda, Maryland 20892; \\ ${ }^{\ddagger}$ Institut Gustave Roussy, 94805 Villejuif Cédex, France; and ${ }^{\S}$ Transgene SA, 67082 Strasbourg Cédex, France
}

\begin{abstract}
A variety of pulmonary disorders, including cystic fibrosis, are potentially amenable to treatment in which a therapeutic gene is directly transferred to the bronchial epithelium. This is difficult to accomplish because the majority of airway epithelial cells replicate slowly and/or are terminally differentiated. Adenovirus vectors may circumvent this problem, since they do not require target cell proliferation to express exogenous genes. To evaluate the diversity of airway epithelial cell targets for in vivo adenovirus-directed gene transfer, a replication deficient recombinant adenovirus containing the Escherichia coli lac $Z$ ( $\beta$-galactosidase [ $\beta$-gal]) gene (Ad.RSV $\beta$ gal) was used to infect lungs of cotton rats. In contrast to uninfected animals, intratracheal Ad.RSV $\beta$ gal administration resulted in $\beta$-gal activity in lung lysate and cytochemical staining in all cell types forming the airway epithelium. The expression of the exogenous gene was dose-dependent, and the distribution of the $\beta$-gal positive airway epithelial cells in Ad.RSV $\beta$ gal-infected animals was similar to the normal cell differential of the control animals. Thus, a replication deficient recombinant adenovirus can transfer an exogenous gene to all major categories of airway epithelial cells in vivo, suggesting that adenovirus vectors may be an efficient strategy for in vivo gene transfer in airway disorders such as cystic fibrosis. (J. Clin. Invest. 1993. 91:225-234.) Key words: cystic fibrosis $\bullet$ gene therapy $\bullet \beta$-galactosidase $\bullet$ cotton rat $\bullet$ lung
\end{abstract}

\section{Introduction}

Cystic fibrosis $(\mathrm{CF})^{1}$, one of the most common lethal hereditary disorders of Caucasians, has its major manifestations in the lung, with respiratory failure responsible for $95 \%$ of deaths of affected individuals $(1,2)$. In the context that $\mathrm{CF}$ is an autosomal recessive disorder involving a single gene (3-5), the respiratory manifestations of CF are potentially amenable to treatment by somatic gene therapy, where the normal human cystic

Address correspondence and reprint requests to Andrea Mastrangeli, M.D., Pulmonary Branch, Room 6D03, Building 10, National Institutes of Health, Bethesda, MD 20892. 1992.

Received for publication 6 April 1992 and in revised form 21 August

1. Abbreviations used in this paper: Ad5, adenovirus type 5; $\alpha 1 \mathrm{AT}$, $\alpha 1$-antitrypsin; CF, cystic fibrosis; CFTR, cystic fibrosis transmembrane conductance regulator; $\beta$-gal, $\beta$-galactosidase; RSV, Rous sarcoma virus; pfu, plaque-forming units; X-Gal, 5-bromo-4-2-chloro-3indolyl- $\beta$-D-galactoside.

The Journal of Clinical Investigation, Inc.

Volume 91, January 1993, 225-234 fibrosis transmembrane conductance regulator (CFTR) cDNA and appropriate controlling elements are transferred directly to the airway epithelium. The feasibility of this approach has been demonstrated in vivo in experimental animals with a replication deficient recombinant adenovirus containing the normal CFTR cDNA (6).

The adenovirus has a number of features that make it suitable for somatic gene therapy (7-13). First, it can be rendered replication deficient, so that it will deliver an exogenous gene to the target cells without subsequent replication of the virus. Second, it can be modified to accept exogenous pieces of DNA $\leq 7.5 \mathrm{~kb}$. Third, in regard to potential safety issues, live adenoviruses are used for in vivo human vaccination, and, although adenoviruses are common human pathogens, no human neoplasms have been associated with adenovirus infection. Fourth, adenovirus can be produced in high titers, a critical requirement for in vivo somatic gene therapy. Finally, some types of adenovirus are tropic for the respiratory epithelium.

In regard to successful gene therapy for $\mathrm{CF}$, the tropism for the respiratory epithelium is very important, since it is in the airway epithelium that the consequences of mutations of the CFTR gene are most dramatic, with abnormal mucus, bacterial colonization, and inflammation that eventually lead to airway derangement and respiratory failure $(1,2)$. All available evidence suggests these abnormalities are a consequence of expression of the mutant CFTR gene in all types of airway epithelial cells (3-5, 14-21). In the normal lung, the airway epithelium is comprised of four major cell categories: ciliated, secretory, basal, and undifferentiated cells (22-24). In this context, for gene therapy for the respiratory manifestations of $\mathrm{CF}$ to be successful, it likely will be necessary to deliver the exogenous gene to all types of airway epithelial cells; i.e., for the adenovirus to be a suitable vector for gene therapy for $\mathrm{CF}$, it must be capable of transferring the exogenous gene to all of the major cell types of the airway epithelial sheet.

Based on this background, the present study is directed toward defining the cell target specificity of a recombinant adenovirus in the airway epithelium in vivo. To answer this question, we have used a replication deficient recombinant adenovirus containing the Escherichia coli lac $Z$ ( $\beta$-galactosidase [ $\beta$-gal]) reporter gene (Ad.RSV $\beta$ gal) to identify the specific airway cell types to which a recombinant adenovirus can transfer and express an exogenous gene in vivo.

\section{Methods}

Adenoviral vectors. The recombinant adenoviral vector Ad.RSV $\beta$ gal (25) was constructed from the adenovirus type 5 (Ad5) deletion mutant, Ad-d 1324 (26), by adding to the left end (by homologous recombination) a lac $Z$ expression cassette containing the $E$. coli lac $Z$ gene (Fig. 1). Ad-d1 324 is based on Ad5, but with deletions of the majority of Ela and $\mathrm{E} 1 \mathrm{~b}$ and a portion of the E3 regions. The remainder of the left end 
Ad5

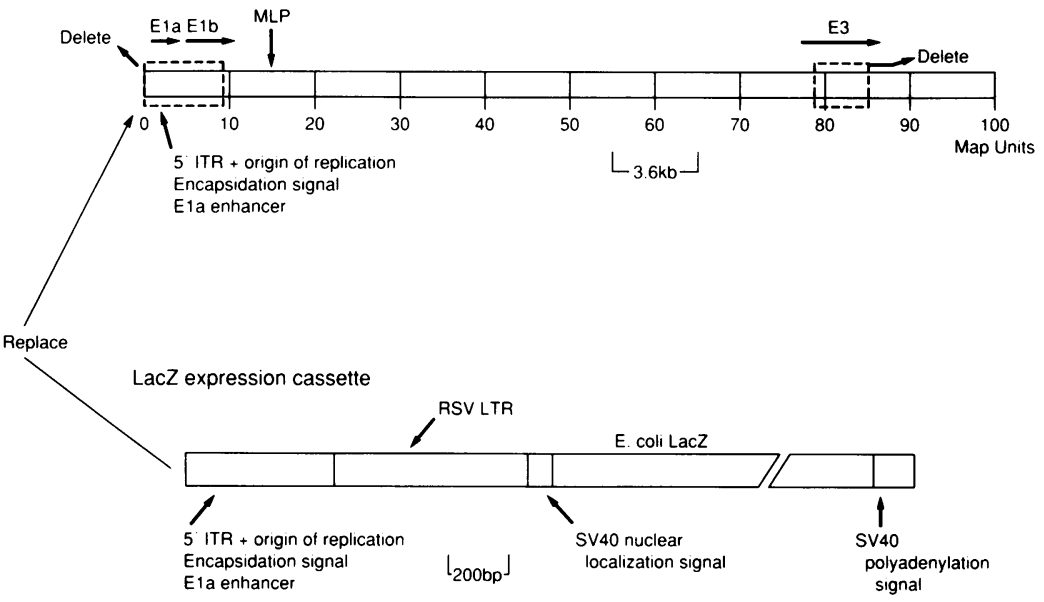

Figure 1. Recombinant adenoviral vector containing the $E$. coli $\beta$-galactosidase gene (lacZ). Shown schematically are the wild type adenovirus type 5 (Ad5) genome and the details of the lac $Z$ expression cassette. Ad5 DNA is divided into 100 map units $(\mathrm{mu})(100$ $\mathrm{mu}=36 \mathrm{~kb}$ ). The recombinant vector (Ad.RSV $\beta$ gal) is constructed from the Ad5-derived virus Ad-d1324, which has a deletion of the majority of the Ela and $\mathrm{E} 1 \mathrm{~b}$ and a portion of $\mathrm{E} 3$ regions. The lac $Z$ expression cassette includes $\left(5^{\prime}\right.$ to $\left.3^{\prime}\right)$ : the left $455 \mathrm{bp}$ of the human Ad5 genome (including the sequences of the inverted terminal repeat [ITR], the origin of DNA replication, the encapsidation signal, and the enhancer of the Ela promoter), followed by the Rous sarcoma virus-long terminal repeat (RSV-LTR) promoter and the SV40 nuclear localization signal, the $E$. coli lacZ gene, the polyadenylation signal from the early region of SV40, and bp 3329-6641 from Ad5. The lacZ expression cassette is added to the left end of Ad-d1324 by homologous recombination following a $\mathrm{ClaI}$ cut of the Ad-d1324 DNA. of the viral genome, including what was left of Ela, was removed during the homologous recombination to produce Ad.RSV $\beta$ gal. The expression cassette contained the $3^{\prime}$ long terminal repeat of the Rous sarcoma virus (RSV), the nuclear localization signal of the SV40 T antigen, and the lacZ gene (27-29). The replication deficient recombinant adenovirus vector Ad- $\alpha 1$ AT containing the human $\alpha 1$-antitryp$\sin (\alpha 1 \mathrm{AT}) \mathrm{cDNA}$ was used as a control $(13,30)$. Stocks of Ad.RSV $\beta$ gal and Ad- $\alpha 1 \mathrm{AT}$ were propagated using the transformed human embryonic kidney cell line 293 (CRL 1573; American Type Culture Collection, grown in improved minimal essential medium (Biofluids, Inc., Rockville, MD) containing 10\% FCS, $2 \mathrm{mM}$ glutamine, $50 \mathrm{U} / \mathrm{ml}$ penicillin, and $50 \mu \mathrm{g} / \mathrm{ml}$ streptomycin, as previously described (31). All viral preparations were purified by $\mathrm{CsCl}$ density centrifugation (32), dialyzed, and stored in virus dialysis buffer $(10 \mathrm{mM}$ Tris- $\mathrm{HCl}, \mathrm{pH} 7.4,1$ $\mathrm{mM} \mathrm{MgCl}$ and $10 \%$ glycerol) at $-70^{\circ}$ before use. Titers of viral stocks were determined by plaque assay on 293 cells (31). Evaluation of the purified Ad.RSV $\beta$ gal preparation using a colorimetric analysis for $\beta$ gal with 2-nitrophenyl- $\beta$-D-galactopyranoside as a substrate and detection at $420 \mathrm{~nm}$ (33) demonstrated no detectable activity.

In vivo infection of cotton rat lungs. The experimental animals used were cotton rats (Sigmoidon hispidus, 6-8 wk) of either sex. To infect the airway epithelium of cotton rats in vivo, the animals were anesthetized by methoxyfluorane inhalation (13). The trachea was exposed by anterior midline incision and Ad.RSV $\beta$ gal $\left(10^{7}-10^{11}\right.$ plaque-forming units [pfu] diluted to a total volume of $300 \mu$ l with PBS, pH 7.4 [Whittaker Bioproducts, Walkersville, MD]) was instilled into the trachea. Since the object of the study was to evaluate airway epithelial cell targets (in contrast to alveolar epithelial cells), the intratracheal infusions were done slowly as a single aliquot of small volume $(300 \mu \mathrm{l})$, with the aim to have the adenovirus vector reach primarily the bronchial tree. As controls, other animals received intratracheal PBS (with glycerol at the same final concentration contained in the diluted virus used for the infection) or an equivalent amount of pfu of Ad- $\alpha 1 \mathrm{AT}$.

E. coli lacZ gene expression. In initial studies to demonstrate that the lac $Z$ gene could be transferred to the airway epithelium in vivo, Ad.RSV $\beta$ gal was instilled into the trachea and the animals were killed $72 \mathrm{~h}$ later. Blood was removed by cardiac puncture, and lungs and trachea were isolated. The lungs were lavaged twice with $2 \mathrm{ml} \mathrm{PBS}$, and the pulmonary vasculature perfused with PBS. The lungs were removed and evaluated by colorimetric and cytochemical analysis. The colorimetric assay of $\beta$-gal activity was performed on homogenate lung lysates, using 2 -nitrophenyl- $\beta$-D-galactopyranoside as a substrate, as described above. The total protein content of the lung lysates was also quantified using a modification of the Lowry method (BCA protein assay; Pierce Chemical Co., Rockford, IL). The effect of increasing doses of Ad.RSV $\beta$ gal $\left(10^{7}-10^{10} \mathrm{pfu} / \mathrm{animal}\right)$ on the expression of the lac $Z$ gene in cotton rat lungs in vivo was evaluated by colorimetric assay as described above. For the cytochemical analysis, the lungs were removed and fixed by slow injection via the trachea of $2 \mathrm{ml}$ of cold fixing solution ( $2 \%$ formaldehyde and $0.2 \%$ glutaraldehyde in PBS) with an instillation pressure of $25 \mathrm{~cm} \mathrm{H}_{2} \mathrm{O}$. The lungs were then immersed in the same fixing solution ( $60 \mathrm{~min}, 4^{\circ}$ ), washed with PBS, and stained by intratracheal infusion and immersion in $5 \mathrm{mM} \mathrm{K}_{4} \mathrm{Fe}(\mathrm{CN})_{6}$, $5 \mathrm{mM} \mathrm{K}_{3} \mathrm{Fe}_{3}(\mathrm{CN})_{6}$ (Sigma Chemical Co., St. Louis, MO) and $2 \mathrm{mM}$ $\mathrm{MgCl}_{2}$ (Mallinckrodt) in PBS containing $0.5 \mathrm{mg} / \mathrm{ml}$ of the X-Gal stain ([5-bromo-4-chloro-3-indolyl- $\beta$-D-galactopyranoside; Boehringer Mannheim Corp., Indianapolis, IN] dissolved in $N, N$-dimethylformamide [Sigma Chemical Co.] at $20 \mathrm{mg} / \mathrm{ml}$, before dilution into the reaction mixture) for $6 \mathrm{~h}, 37^{\circ}(34,35)$. Tissues were identified as positive for $\beta$-gal activity by the blue stain of the X-Gal reaction.

To evaluate the diversity of airway epithelial cell targets for in vivo adenovirus-mediated gene transfer, the study was designed to analyze direct lac $Z$ transfer and expression before the time the Ad.RSV $\beta$ galinfected cells could proliferate and differentiate and the daughter cells express the $l a c Z$ gene. In this context, all analyses were carried out $24 \mathrm{~h}$ after Ad.RSV $\beta$ gal instillation. The 24-hr time point was chosen based on two lines of evidence: (a) preliminary studies demonstrating $\beta$-gal activity 6-10 $\mathrm{h}$ after exposure of an epithelial cell line to Ad.RSV $\beta$ gal (not shown); and (b) extensive studies in the literature demonstrating that the airway epithelium proliferates very slowly, with $<1 \%$ airway cells entering the proliferative cycle within $24 \mathrm{~h}(23,36,37)$.

The Ad.RSV $\beta$ gal vector was instilled as described above, and the animals were killed $24 \mathrm{~h}$ later. The lungs were handled and stained with $\mathrm{X}-\mathrm{Gal}$ as described above. To obtain sections of the proximal bronchi and distal bronchioles, both lungs were then sliced longitudinally along the axis of the main bronchi (38). The samples were embedded in paraffin or glycomethacrylate using standard techniques. Paraffin sections $(5 \mu \mathrm{m})$ and glycomethacrylate sections $(2 \mu \mathrm{m})$ were analyzed unstained, as well as after counterstaining, with hematoxylin-eosin, hematoxylin only, or nuclear fast red. Quantification of airway epithelial cells was performed on sections counterstained with hematoxylin and nuclear fast red, by light microscopy at a magnification of 1,000 under oil immersion. For each animal, control or infected, two sections of both lungs were analyzed. All sections were evaluated (see below for criteria) for $(a)$ the relative proportion of the different types of airway epithelial cells; and $(b)$ the types of lac $Z$ positive airway epithelial cells. Differential cell counts were performed at two levels of the airways: $(a)$ in proximal intrapulmonary bronchi (diameter 200-700 $\mu \mathrm{m}$ ); and (b) in distal bronchioles (diameter $<200 \mu \mathrm{m}$ ). A total of eight animals received Ad.RSV $\beta$ gal; from this group a total of 5,300 cells were scored 
in the proximal airways and 3,300 cells in the distal airways. Epithelial cells in the proximal and distal airways were scored as positive for the expression of the lac $Z$ product if the characteristic $\beta$-gal blue color was nuclear/perinuclear or nuclear/perinuclear and in the cytoplasm. For the PBS control animals $(n=8)$, a total of 6,500 proximal and 4,700 distal airway cells were evaluated. For the Ad- $\alpha 1$ AT controls $(n=5)$, a total of 2,900 proximal and 2,900 distal airway cells were evaluated. Only cells with visible sectioned nuclei were considered.

In the proximal bronchi, airway epithelial cells were classified in four categories (ciliated cells, secretory cells, basal cells, and undifferentiated cells) based on the following criteria. Ciliated cells had faintly stained oval shaped nuclei, columnar profiles, and cilia and/or terminal plates at the surface. Secretory cells had no cilia, goblet, or columnar shapes and clear, large vacuoles or small darkly stained granules. Basal cells were small angular shaped cells adjacent to the basal membrane with dense round nuclei, strongly stained cytoplasm, and high nuclear to cytoplasmic ratio. Undifferentiated cells were cells that did not meet any of the criteria listed above.

In the distal bronchioles, airway epithelial cells were also classified into four categories (ciliated cells, secretory cells, basal cells, and undifferentiated cells). Ciliated cells were similar to those in the proximal airway, but were cuboidal shaped. Secretory cells were "golf club" shaped with a smooth surface projecting high above the surrounding ciliated cells; these cells were mainly Clara cells. Basal and the undifferentiated cells had a similar appearance to that described above for the proximal airways.

Statistical evaluation. All data are expressed as mean \pm SEM, and all statistical comparisons were done with the two-tailed Student's $t$ test.

\section{Results}

In vivo adenovirus-directed $E$. coli lac $Z$ gene expression. After intratracheal administration of Ad.RSV $\beta$ gal to cotton rats, the presence of $\beta$-gal activity in the lungs could be detected by colorimetric assay (Fig. 2). Evaluation of lung lysates of animals injected with intratracheal $\operatorname{PBS}(n=5)$ or the control virus Ad- $\alpha$ 1 AT $\left(10^{10}\right.$ total pfu/animal; $\left.n=5\right)$, using a $\beta$-gal colorimetric assay was negative, but $\beta$-gal activity was present in lung lysates of animals infected with Ad.RSV $\beta$ gal $\left(10^{10}\right.$ total pfu/animal; $n=3$ ). The $\beta$-gal activity was $6.4 \pm 2.0 \times 10^{-2} \mathrm{U} / \mathrm{mg}$ of cellular protein. Importantly the $\beta$-galactosidase activity in lungs of animals administered increasing doses of Ad.RSV $\beta$ gal was dose-dependent. Consistent with the colorimetric data, cytochemical analysis of the lungs of animals that received intratracheal PBS (Fig. $3 A$ ) or the control virus Ad- $\alpha$ 1AT (not shown) did not show blue staining; i.e., no $\beta$-gal activity was detected. In contrast, lungs of animals instilled with Ad.RSV $\beta$ gal appeared intensely blue with $\beta$-gal activity localized to the airways $(B)$.

A variety of different light microscopic histologic methods all demonstrated that after Ad.RSV $\beta$ gal intratracheal instillation, the bronchial epithelium of animals could be infected with Ad.RSV $\beta$ gal and expressed intracellular $\beta$-gal activity at all airway segments evaluated (Fig. 4). In this regard, after instillation of PBS, no $\beta$-gal activity was noted in the airway epithelium $(A)$. In contrast, instillation of Ad.RSV $\beta$ gal resulted in clear expression of $\beta$-gal predominantly in the airway epithelium $(B) . \beta$-gal activity was absent in the airways of control animals in paraffin sections evaluated with a nuclear fast red counterstain ( $A$ and $G$ ). The same was true in paraffin sections stained with hematoxylin-eosin $(C)$ and in frozen sections not counterstained $(E)$. Likewise, after intratracheal administration of the control virus Ad- $\alpha 1 \mathrm{AT}$, no $\beta$-gal activity was observed in the airway epithelium with any of these histologic

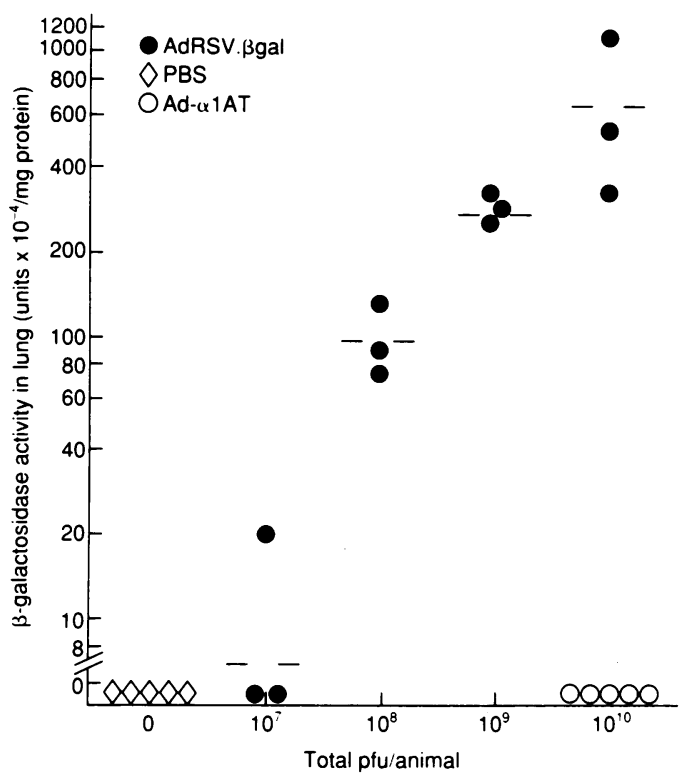

Figure 2. $\beta$-galactosidase activity in lysates of cotton rat lungs after intratracheal infection with increasing doses of Ad.RSV $\beta$ gal. Lungs were evaluated $72 \mathrm{~h}$ after infection by colorimetric analysis using a $\beta$-galactosidase specific substrate. The data are presented as $\beta$-galactosidase activity/total protein. Each data point represents a single animal. Shown is data for Ad.RSV $\beta$ gal (•), and control animals injected with PBS $(0)$ and those infected with $\operatorname{Ad}-\alpha 1 \mathrm{AT}(0)$. For each dose of virus the horizontal lines indicate the mean of the $\beta$-galactosidase activity.

methods (not shown). In contrast, with all sectioning and counterstaining methods, $\beta$-gal activity was clearly observed in the airway epithelium after Ad.RSV $\beta$ gal administration $(B, D, F$, and $H$ ).

When counterstained with nuclear fast red, examination of the airway epithelium of animals receiving intratracheal PBS or the control virus Ad- $\alpha 1$ AT demonstrated no blue staining of the airway epithelial cells (Fig. 5, $A-F$ ); i.e., no endogenous cytoplasmic $\beta$-galactosidase activity was detected in the airway epithelium. As an additional control, thyroid tissues from the same animals stained with the X-Gal stain showed endogenous cytoplasmic $\beta$-galactosidase activity (not shown).
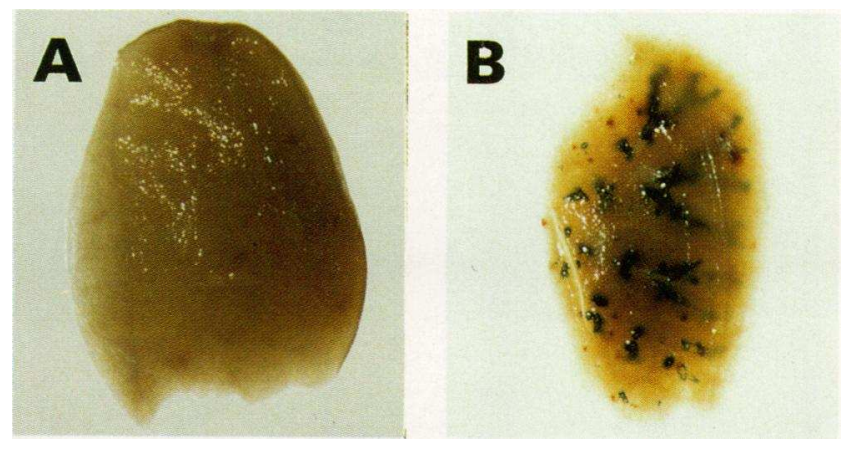

Figure 3. Cotton rat lungs infected in vivo with Ad.RSV $\beta$ gal. (Panel $A$ ) Section of left lung of an animal receiving intratracheal PBS as a negative control. (Panel $B$ ) Section of left lung of an animal receiving intratracheal Ad.RSV $\beta$ gal. The lungs were removed $72 \mathrm{~h}$ after injection and stained for $\beta$-galactosidase activity; the blue color indicates $\beta$-galactosidase activity. 

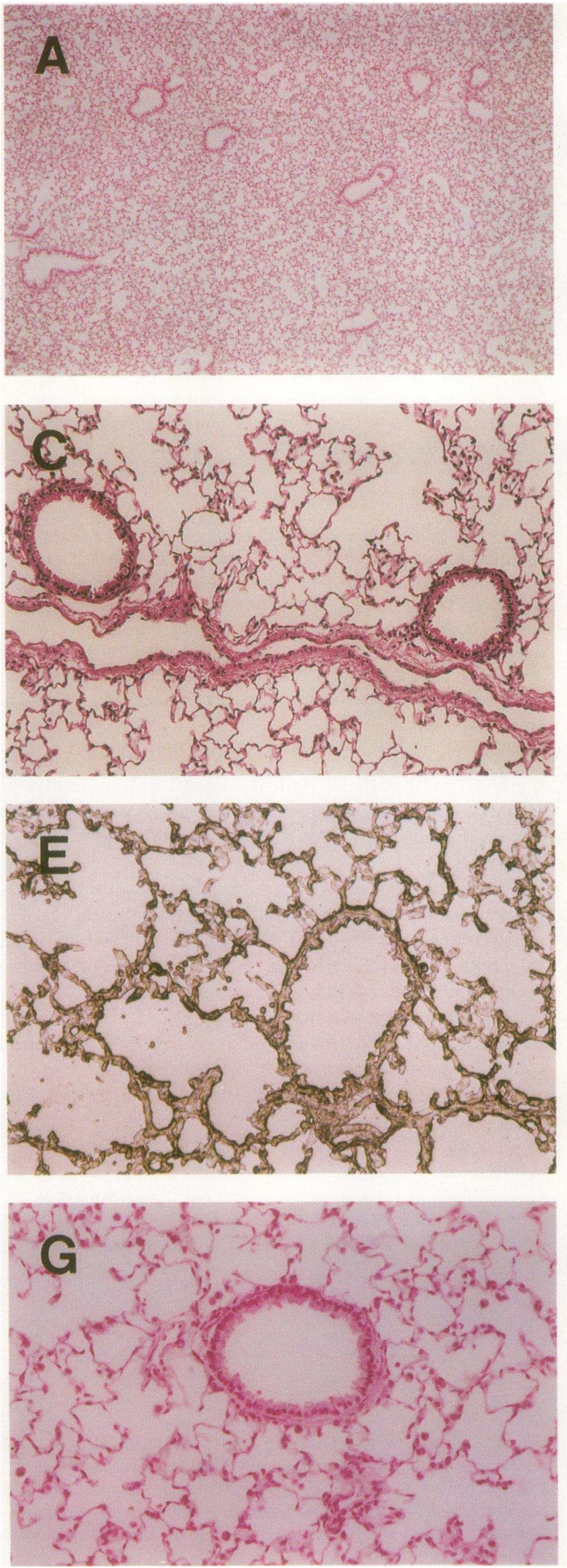

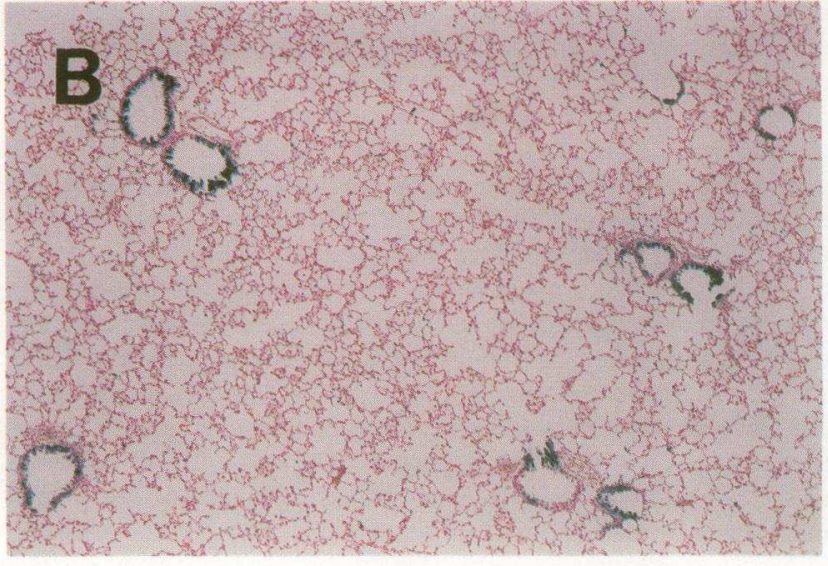

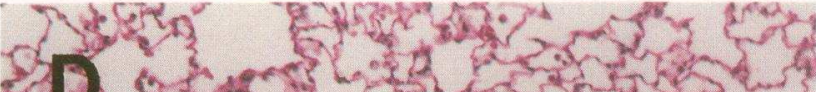

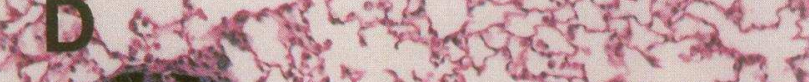

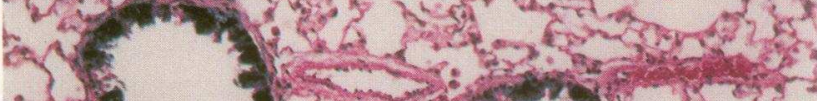

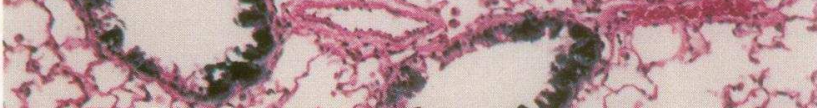

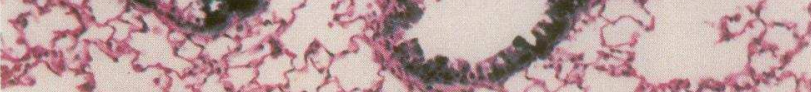
का 2.

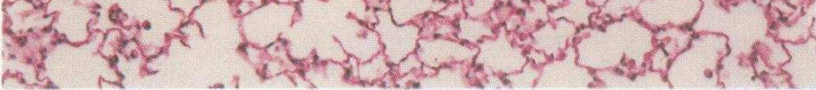
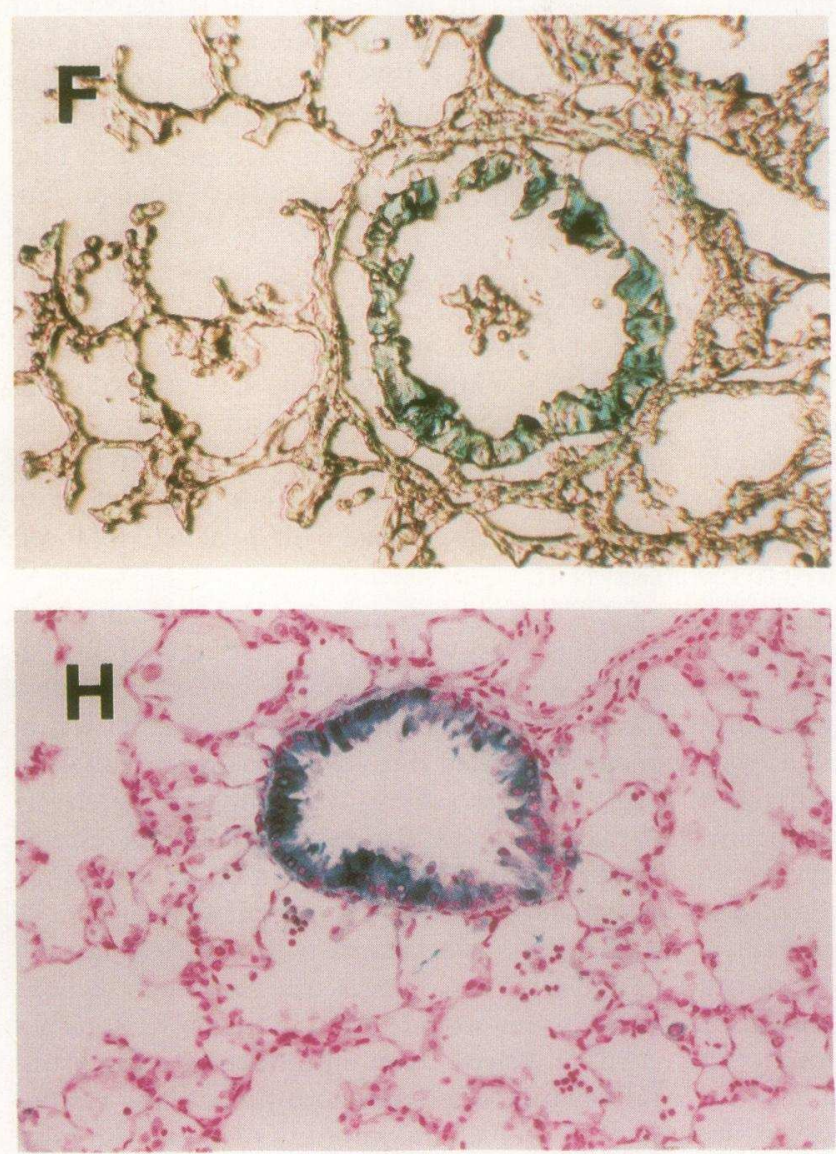

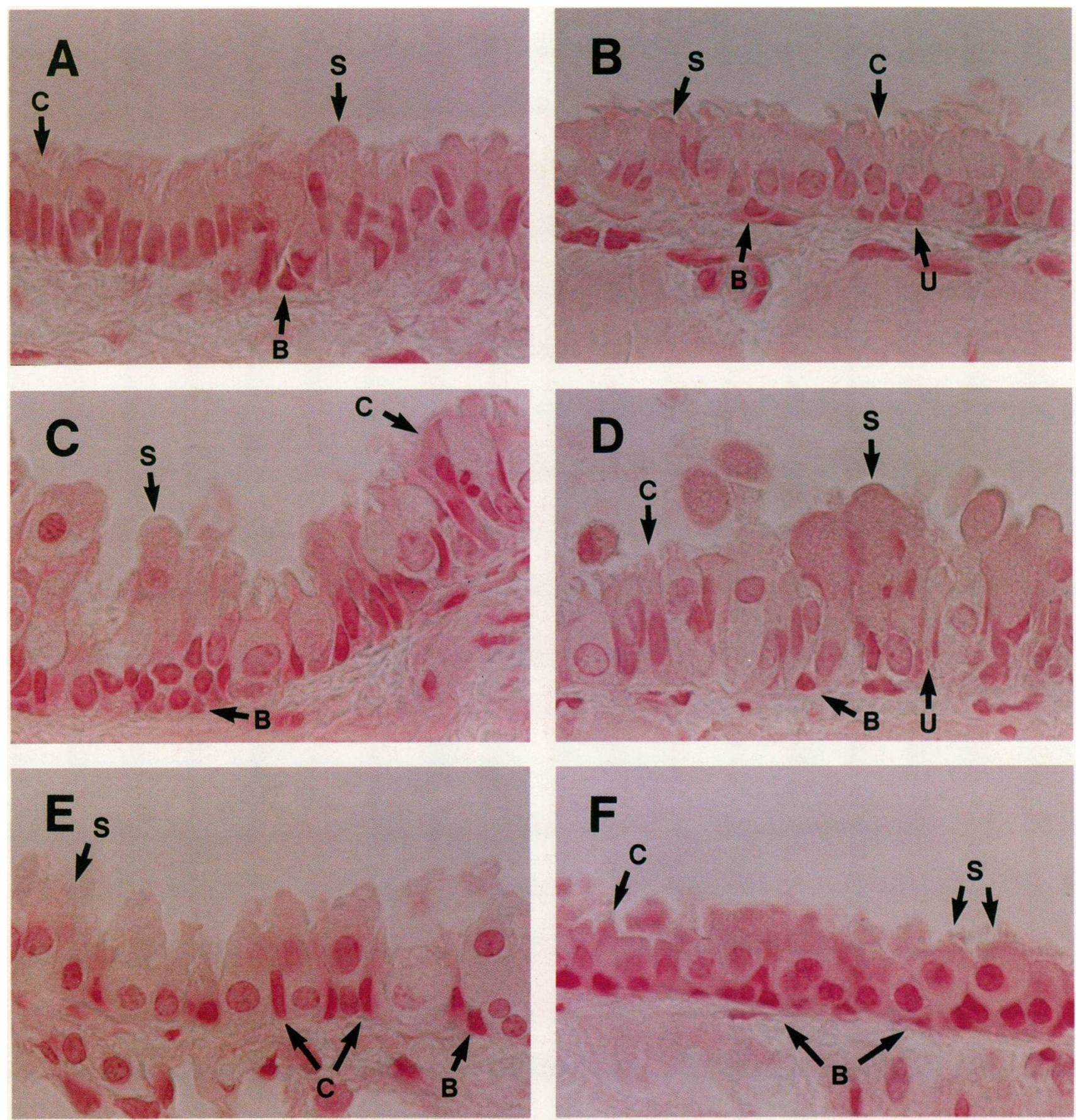

Figure 5. Bronchial epithelial cells in cotton rats $24 \mathrm{~h}$ after in vivo administration of intratracheal PBS or control virus Ad- $\alpha 1 \mathrm{AT}$. Lungs were stained for $\beta$-galactosidase activity. (Panels $A$ and $B$ ) Details of bronchial epithelial cells from animals receiving intratracheal PBS, plastic sections, nuclear fast red counterstain, $\times 1,000$; arrows indicate ciliated cells $(C)$, secretory cells $(S)$, undifferentiated cells (U), and basal cells (B). (Panels $C$ and $D$ ) Details of bronchial epithelial cells from animals receiving intratracheal Ad- $\alpha 1$ AT, plastic sections, nuclear fast red counterstain, $\times 1,000$; arrows indicate ciliated cells $(C)$, secretory cells $(\mathrm{S})$, undifferentiated cells $(\mathrm{U})$, and basal cells (B). (Panel $E$ ) Bronchiole epithelial cells from animal receiving intratracheal PBS, plastic section, nuclear fast red counterstain, $\times 1,000$; arrows indicate ciliated cells (C), secretory cells (S), and basal cells (B). (Panel $F$ ) Bronchiole epithelial cells from animal receiving intratracheal Ad- $\alpha 1 \mathrm{AT}$, plastic section, nuclear fast red counterstain, $\times 1,000$; arrows indicate ciliated cells $(C)$, secretory cells $(S)$, and basal cells $(B)$.

Figure 4. $\beta$-galactosidase activity in lungs from animals receiving intratracheal Ad.RSV $\beta$ gal in vivo. The lungs were stained for $\beta$-galactosidase activity before sectioning; the blue color indicates the cells expressing $\beta$-galactosidase activity (Panel $A$ ) $24 \mathrm{~h}$ after intratracheal PBS, paraffin section, nuclear fast red counterstain, $\times 50$. Panel $B$. Same as $A$, but $24 \mathrm{~h}$ after Ad.RSV $\beta$ gal. (Panel $C$ ) $72 \mathrm{~h}$ after intratracheal PBS, paraffin section, hematoxylin-eosin counterstain, $\times 100$ (Panel $D$ ) Same as $C$, but $72 \mathrm{~h}$ after Ad.RSV $\beta$ gal. (Panel $E$ ) $72 \mathrm{~h}$ after intratracheal PBS, frozen section, no counterstain, $\times 200$. (Panel $F$ ) Same as $E$, but $72 \mathrm{~h}$ after Ad.RSV $\beta$ gal. (Panel $G$ ) $24 \mathrm{~h}$ after intratracheal PBS, paraffin section, nuclear fast red counterstain, $\times 200$. (Panel $H$ ) same as $G$, but 24 h after Ad.RSV $\beta$ gal. 

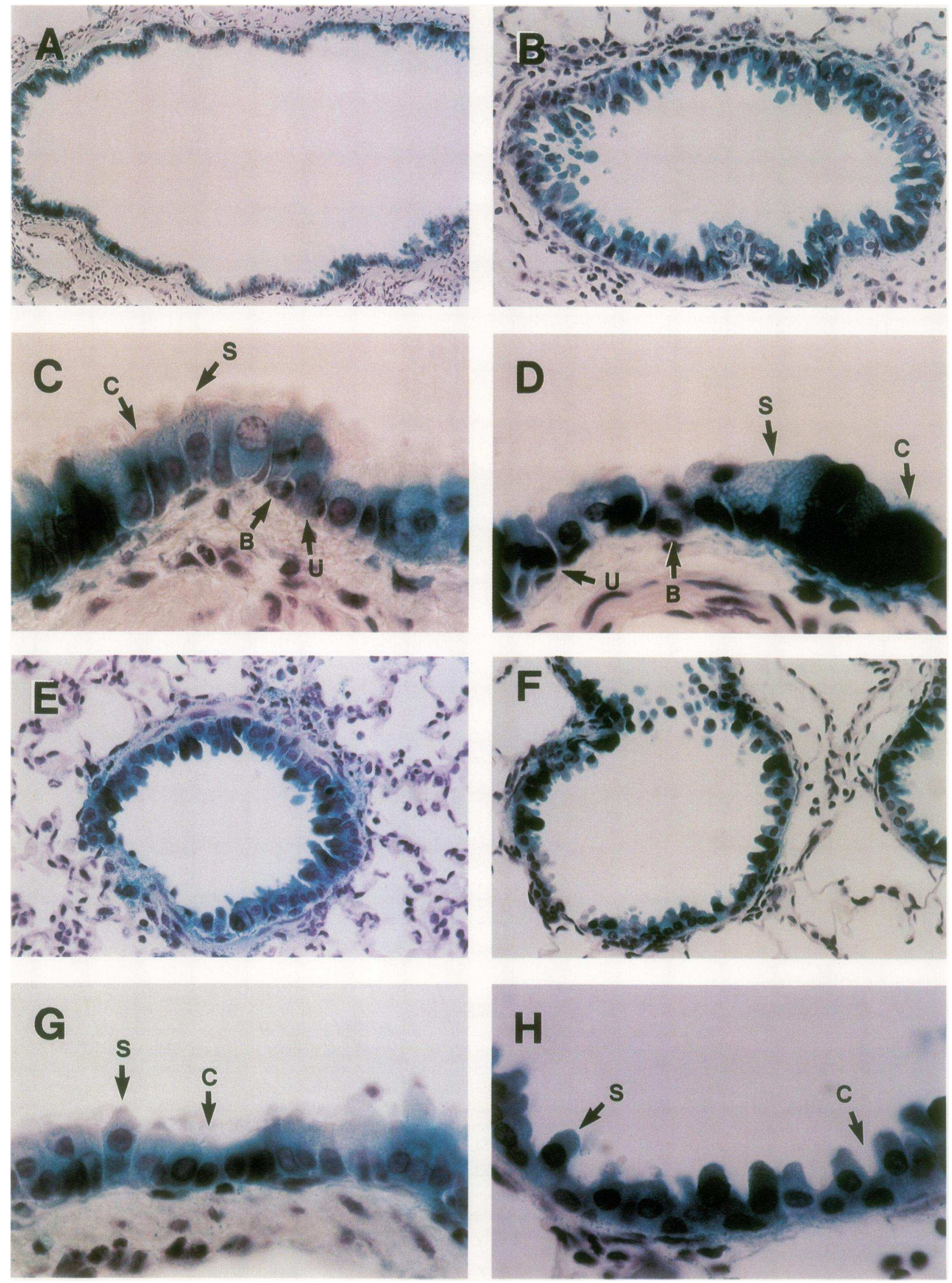
In contrast to the controls, the airway epithelium of animals receiving intratracheal Ad.RSV $\beta$ gal demonstrated that all categories of airway epithelial cells expressed the lac $Z$ gene (Figs. 6 and 7). This was true for the proximal bronchi (Fig. 6, $A$ and $B$ ), including ciliated, secretory, undifferentiated (Fig. 6, $C$ and $D$ ) and basal cells (Fig. 6, $C$ and $D$; Fig. 7, $A-D$ ). It was also observed in the bronchioles (Fig. 6, $E$ and $F$ ), including ciliated cells, secretory (Clara cells), and the less common undifferentiated (Fig. 6, $G$ and $H$ ) and basal cells (Fig. 6, $G$ and $H$; Fig. 7, $E$ and $F)$. Particular attention was dedicated to the identification of $\beta$-galactosidase positive basal cells because these cells have a high nuclear/cytoplasmic ratio, and thus it can be difficult to distinguish positive nuclear and perinuclear $\beta$-galactosidase staining from the hematoxylin stained dark blue nuclei. This may be particularly difficult in regions where all of the neighboring cells express the exogenous $\beta$-galactosidase gene. In this regard, sections were counterstained with nuclear fast red (i.e., so that there would be no confusion with blue stain other than the X-Gal stained $\beta$-galactosidase), and regions were evaluated where basal cells were observed in areas with minimal expression of $\beta$-galactosidase in neighboring epithelial cells (i.e., so there would be no confusion with blue staining from neighboring cell types). The data convincingly demonstrated that the basal cells of animals receiving Ad.RSV $\beta$ gal, but not controls, expressed the exogenous $\beta$-galactosidase gene (Figs. 5 and 7).

Quantitative evaluation of the diversity of Ad.RSVBgal targets. Quantification of the distribution of $\beta$-gal positive cells was evaluated using two different counterstains (hematoxylin and nuclear fast red). After Ad.RSV $\beta$ gal administration, the adenovirus vector delivered the lac $Z$ gene to all categories of airway epithelial cells with the distribution of expression of the lac $Z$ product similar to the normal distribution of the various epithelial cell types in control animals (Fig. 8). This was true both in proximal bronchi ( $A$ and $C$ ) and in the bronchioles ( $B$ and $D$ ). In the large airways of uninfected animals, ciliated and secretory cells predominated with smaller numbers of basal cells and relatively few undifferentiated cells $(A)$. The same cell differential was found in animals receiving intratracheal PBS or the control virus Ad- $\alpha$ 1AT (not shown). After intratracheal instillation of Ad.RSV $\beta$ gal, the lac $Z$ product was observed among all of the cell types in the large airway epithelial sheet, and in similar proportion to the normal distribution of epithelial cell types ( $A$ and $C ; P>0.1$, all comparisons of the proportion of lac Z positive cells to the normal distribution of cell types). Importantly, the differential counts of basal cells in control animals and $\beta$-galactosidase positive basal cells in Ad.RSV $\beta$ gal injected animals showed identical results with the nuclear fast red and hematoxylin counterstains $(P>0.1)$.

The same distribution was found in the small airways. In control animals, ciliated and secretory cells predominated (Fig.
$8 \mathrm{~B}$ ). Basal cells and undifferentiated cells were relatively rare. Similar observations were made in the animals receiving PBS or the control virus Ad- $\alpha$ 1AT (not shown). Analysis of the distribution of bronchiolar epithelial cells expressing the lac $Z$ gene after Ad.RSV $\beta$ gal administration showed a pattern similar to the normal cell distribution ( $B$ and $D ; P>0.1$, all comparisons of the proportion of lac $Z$ positive cells to the normal distribution of cell types). The same differential counts of basal cells in control animals, and of $\beta$-galactosidase positive basal cells in animals injected with Ad.RSV $\beta$ gal, were observed with the nuclear fast red counterstain as with hematoxylin counterstain $(P>0.1)$.

\section{Discussion}

A possible approach to therapy of respiratory manifestations of cystic fibrosis is organ-specific delivery of the normal gene to the respiratory epithelium of affected individuals. The feasibility of this approach has been demonstrated in experimental animals using a recombinant replication deficient adenovirus containing the normal human cystic fibrosis transmembrane conductance regulator cDNA (6). While these studies demonstrated that the recombinant vector could transfer an exogenous gene to the airway epithelium in vivo, the distribution of epithelial cell types expressing the exogenous gene is unknown. The answer is critical because if this approach to gene therapy of CF is to work, it may be necessary for the exogenous gene to be delivered to all airway epithelial cells requiring CFTR for their normal function. Which airway epithelial cells must express CFTR is not known, but all available evidence suggests that all major categories of airway epithelial cells express CFTR (3-5, 14-21). Thus, at least until evidence is produced to the contrary, the objective for gene therapy for the respiratory manifestations of CF is to deliver the normal gene to all categories of the airway epithelium, including large to small airways.

The present study answers this question for adenovirus vectors, using the lac $Z$ reporter gene to identify target cells. The data demonstrate that a replication deficient recombinant adenovirus vector can transfer an exogenous gene in a dose-dependent fashion to the epithelium of all segments of the intrapulmonary airways. Importantly, the composition of the epithelial cell population expressing the transferred gene is similar to the cell distribution in the normal epithelium; i.e., intratracheal administration of an adenovirus vector is capable of transferring an exogenous marker gene to all categories of airway epithelial cells. In the context that intratracheal administration of a recombinant adenovirus vector containing the normal human CFTR cDNA results in expression of the transferred gene in the lungs of experimental animals (6), these observations suggest the adenovirus may be a useful vector for gene therapy for the respiratory manifestations of cystic fibrosis. In this re-

\footnotetext{
Figure 6. Bronchial epithelial cells expressing $\beta$-galactosidase activity in cotton rat lung $24 \mathrm{~h}$ after in vivo infection with Ad.RSV $\beta$ gal. Lungs of animals receiving intratracheal Ad.RSV $\beta$ gal were stained for $\beta$-galactosidase activity, indicated by the blue color. (Panel $A$ ) Bronchus, paraffin section, hematoxylin counterstain, $\times 200$. (Panel $B$ ) Bronchus, paraffin section, hematoxylin counterstain, $\times 400$. (Panels $C$ and $D$ ) Details of bronchial epithelial cells, plastic sections, hematoxylin counterstain, $\times 1,000$; arrows indicate ciliated cells (C), secretory cells (S), basal cells (B), and undifferentiated cells $(U)$. (Panel $E$ ) Bronchiole, paraffin section, hematoxylin counterstain, $\times 400$. (Panel $F$ ) Bronchiole, hematoxylin counterstain, $\times 630$. (Panel $G$ ) Detail of bronchiole epithelial cells, paraffin section, hematoxylin counterstain, $\times 1,000$; arrows indicate ciliated cells (C) and secretory cells (S). (Panel $H$ ) Bronchiole epithelial cells (detail), paraffin section, hematoxylin counterstain, $\times 1,000$; arrows indicate ciliated cells (C), secretory cells (Clara cells) (S), and basal cells (B).
} 

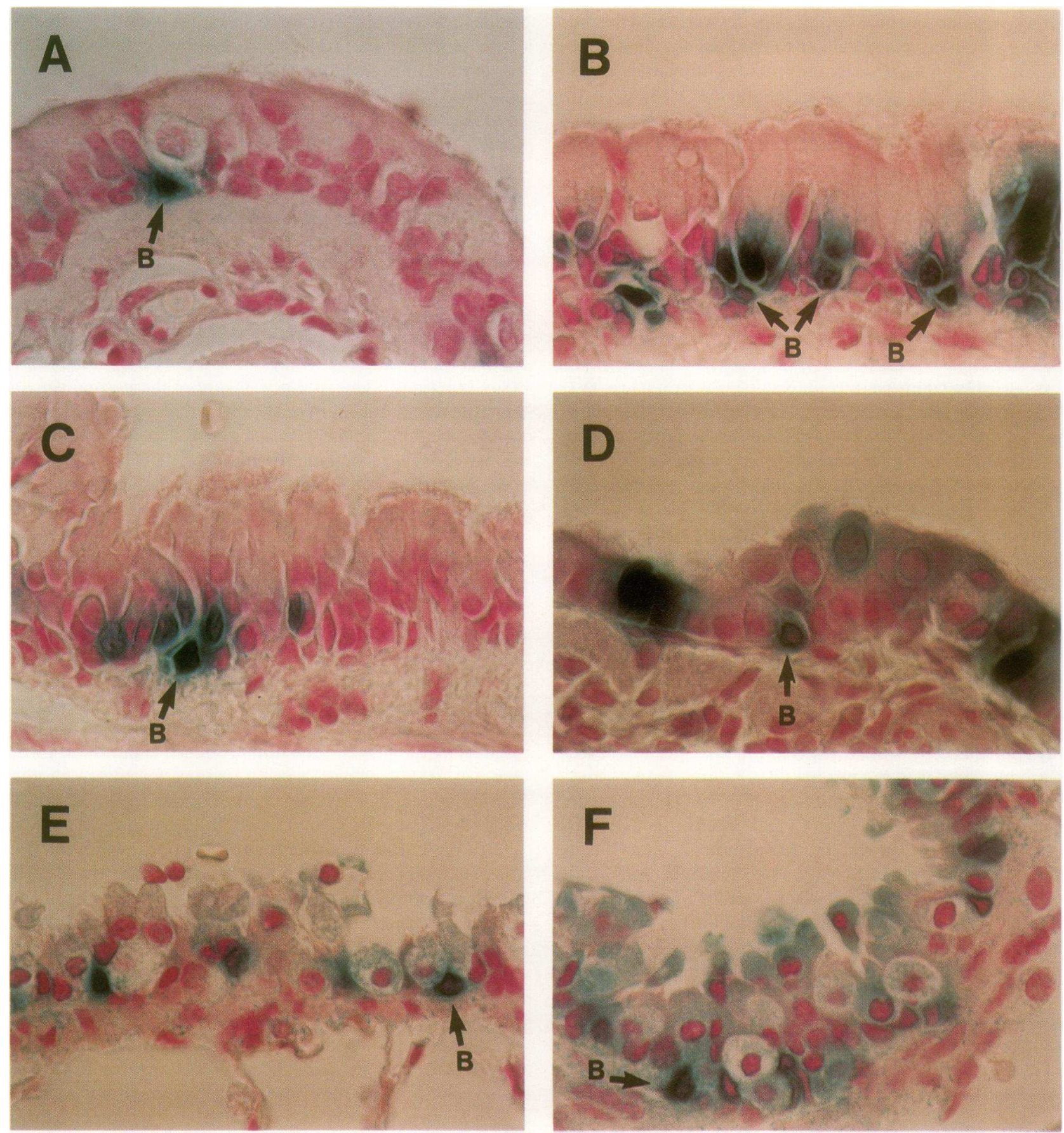

Figure 7. Bronchial basal cells expressing $\beta$-galactosidase activity in cotton rat lungs $24 \mathrm{~h}$ after in vivo infection with Ad.RSV $\beta$ gal. Lungs of animals infected intratracheally with Ad.RSV $\beta$ gal were stained for $\beta$-galactosidase activity indicated by the blue color. (Panels $A-D)$ Details of bronchial epithelial cells, plastic sections, and nuclear fast red counterstain, $\times 1,000$; arrows indicate basal cells (B). (Panels $E$ and $F$ ) Bronchiole epithelial cells (detail), plastic sections, and nuclear fast red counterstain, $\times 1,000$; arrows indicate basal cells (B).

gard, the observation that the transfer of the exogenous gene is dose-dependent may be important, since the level of CFTR expression necessary to correct the disease in vivo is not known.

One caveat regarding this conclusion comes from the knowledge that the airway epithelium of the cotton rats $(S$. hispidus, a rodent that has similarities to rat and hamster) is not identical to that of the human. The cotton rats were used in these studies because of the extensive data suggesting the cotton rat is similar to the human in regard to sensitivity to adenovirus airway infection (39). However, like other rodents and most other experimental animals, the cotton rat large airway epithelium differs from the human in that the cotton rat has significantly higher proportions of surface secretory cells and lower proportions of submucosal glands $(40,41)$. Another caveat relates to the potentially hostile environment of the $C F$ 


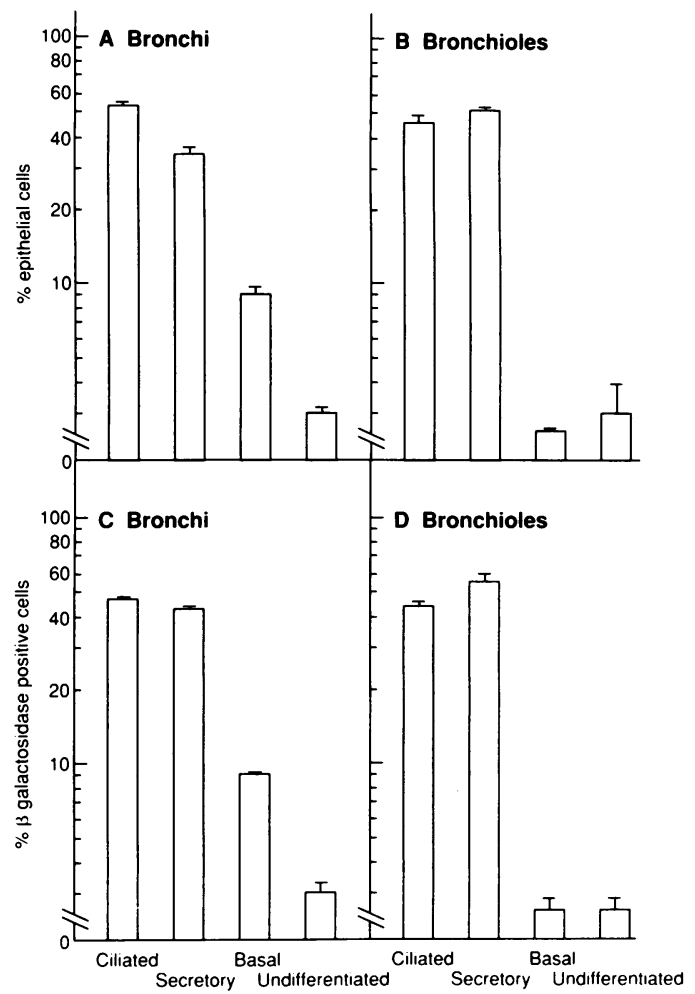

Figure 8. Distribution of airway epithelial cell expression of $\beta$-galactosidase following in vivo intratracheal administration of Ad.RSV $\beta$ gal to cotton rats. (Panel $A$ ) Relative numbers of different categories of epithelial cells in bronchi of uninfected animals. (Panel $B$ ) Relative numbers of different categories of epithelial cells in bronchioles of uninfected animals. (Panel $C$ ) Relative numbers of different categories of $\beta$-galactosidase positive cells in bronchi of animals receiving Ad.RSV $\beta$ gal; the data are expressed as the percent of each cell category expressing $\beta$-galactosidase relative to the total number of airway epithelial cells expressing $\beta$-galactosidase. (Panel $D$ ) Same as $C$, but for bronchioles. Quantification was done using hematoxylin counterstained sections, see Methods for details as to criteria for each cell category, $\beta$-galactosidase positivity, and total number of animals and cells evaluated.

lung for gene transfer using any type of vector. However, since there are no animals that are similar to the human in both the types of respiratory epithelial cells and the sensitivity to human adenoviruses, and no animal model mimicking all the respiratory manifestations of $\mathrm{CF}$, the final answer to these questions will have to wait for human studies.

Adenoviruses have an advantage as vectors for gene therapy because they are common human pathogens, tropic for the respiratory epithelium. However, a majority of adults have detectable serum antibodies against the sero-group $\mathrm{C}$ adenoviruses (including Ad5) (8). Whether this will pose a problem for gene therapy for $\mathrm{CF}$ is difficult to evaluate in vitro or in vivo in animals, because there are no in vitro or in vivo models of the human CF lung.

We have shown that Ad5 based replication deficient recombinant adenovirus clearly infects and transfers an exogenous gene to ciliated and nonciliated epithelium. The observation that ciliated airway epithelial cells express the reporter gene carried by the adenovirus vector lends important support to the concept that adenovirus vectors can transfer genes to nonproliferating, terminally differentiated cells. Ciliated cells are derived from basal, undifferentiated, and possibly secretory airway epithelial cells, but can not proliferate themselves $(22,42,43)$. Importantly, the proportion of the ciliated cells expressing $\beta$ gal in the Ad.RSV $\beta$ gal-infected animals was the same as the proportion of ciliated cells in the control animals. In the context that the observations were made $24 \mathrm{~h}$ after infection, given the slow rate of proliferation of the airway epithelium $(23,36)$, and considering that the exogenous gene takes $6-10 \mathrm{~h}$ to be expressed, the lac $Z$ gene must have been directly transferred and expressed in the ciliated cells.

\section{Acknowledgments}

We thank R. Dreyfuss and S. Everett for help with photomicroscopy, and G. Prince and M. Reddington (laboratory of Infectious Diseases, National Institute of Allergy and Infectious Diseases) for making cotton rats available to us.

This work was supported in part by the American Cystic Fibrosis Foundation and l'Association Française de lutte contre la Mucoviscidose.

\section{References}

1. Boat, T. F., M. J. Welsh, and A. L. Beaudet. 1989. Cystic fibrosis. In The Metabolic Basis of Inherited Diseases. C. R. Scriver, A. L. Beaudet, W. S. Sly, and D. Valle, editors. McGraw-Hill Inc., New York. 2649-2680.

2. Welsh, M. J., and R. B. Fick. 1987. Cystic fibrosis. J. Clin. Invest. 80:15231526.

3. Rommens, J. M., M. C. Iannuzzi, B.-S. Kerem, M. L. Drumm, G. Melmer, M. Dean, R. Rozmahel, J. L. Cole, D. Kennedy, N. Hidaka, et al. 1989. Identification of the cystic fibrosis gene: chromosome walking and jumping. Science (Wash. DC). 245:1059-1064.

4. Riordan, J. R., J. M. Rommens, B.-S. Kerem, N. Alon, R. Rozmahel, Z. Grzelczak, J. Zielenski, S. Lok, N. Plavsic, J.-L. Chou, et al. 1989. Identification of the cystic fibrosis gene: cloning and characterization of complementary DNA. Science (Wash. DC). 245:1066-1073.

5. Kerem, B.-S., J. M. Rommens, J. A. Buchanan, D. Markiewicz, T. K. Cox, A. Chakravarti, M. Buchwald, and L.-C. Tsui. 1989. Identification of the cystic fibrosis gene: genetic analysis. Science (Wash. DC). 245:1073-1080.

6. Rosenfeld, M. A., K. Yoshimura, B. C. Trapnell, K. Yoneyama, E. R. Rosenthal, W. Dalemans, M. Fukayama, J. Bargon, L. E. Stier, L. D. StratfordPerricaudet, et al. 1992. In vivo transfer of the human cystic fibrosis transmembrane conductance regulator gene to the airway epithelium. Cell. 68:143-155.

7. Chanock, R. M., W. Ludwig, R. J. Heubner, T. R. Cate, and L.-W. Chu. 1966. Immunization by selective infection with type 4 adenovirus grown in human diploid tissue culture. JAMA (J. Am. Med. Assoc.). 195:445-552.

8. Straus, S. E. 1984. Adenovirus infections in humans. In The Adenoviruses. H. S. Ginsberg, editor. Plenum Publishing Corp., New York. 451-496.

9. Ballay, A., M. Levrero, M.-A. Buendia, P. Tiollais, and M. Perricaudet. 1985. In vitro and in vivo synthesis of the hepatitis B virus surface antigen and of the receptor for polymerized human serum all from recombinant human adenoviruses. EMBO (Eur. Mol. Biol. Organ.) 4:3861-3865.

10. Haj-Ahmad, Y., and F. L. Graham. 1986. Development of a helper-independent human adenovirus and its use in the transfer of the herpes simplex virus thymidine kinase gene. J. Virol. 10:267-274.

11. Berkner, K. L. 1988. Development of adenovirus vectors for the expression of heterologous genes. Biotechniques. 6:616-629.

12. Horwitz, M. S. 1991. Adenoviridae and their replication. In Virology. B. N. Fields, and D. M. Knipe, editors. Raven Press, Ltd., New York. 1679-1740.

13. Rosenfeld, M. A., W. Siegfried, K. Yoshimura, K. Yoneyama, M. Fukayama, L. E. Stier, P. K. Pääkkö, P. Gilardi, L. D. Stratford-Perricaudet, M. Perricaudet, et al. 1991. Adenovirus-mediated transfer of a recombinant $\alpha 1$-antitrypsin gene to the lung epithelium in vivo. Science (Wash. DC). 252:431-434.

14. Knowles, M., J. Gatzy, and R. Boucher. 1981. Increased bioelectric potential difference across respiratory epithelia in cystic fibrosis. N. Engl. J. Med. 305:1489-1495.

15. Frizzell, R. A., G. Rechkemmer, and R. L. Shoemaker. 1986. Altered regulation of airway epithelial cell chloride channels in cystic fibrosis. Science (Wash. DC). 233:558-560.

16. Li, M., J. D. McCann, C. M. Liedtke, A. C. Nairn, P. Greengard, and M. J. Welsh. 1988. Cyclic AMP-dependent protein kinase opens chloride channels in normal but not cystic fibrosis airway epithelium. Nature (Lond.). 331:358-360.

17. Jetten, A. M., J. R. Yankaskas, M. J. Stutts, N. J. Willumsen, and R. C. 
Boucher. 1989. Persistence of abnormal chloride conductance regulation in transformed cystic fibrosis epithelia. Science (Wash. DC). 244:1472-1475.

18. Rich, D. P., M. P. Anderson, R. J. Gregory, S. H. Cheng, S. Paul, D. M. Jefferson, J. D. McCann, K. W. Klinger, A. E. Smith, and M. J. Welsh. 1990. Expression of cystic fibrosis transmembrane conductance regulator corrects defective chloride channel regulation in cystic fibrosis airway epithelial cells. Nature (Lond.). 347:358-363.

19. Trapnell, B. C. C.-S. Chu, P. K. Pääkkö, T. C. Banks, K. Yoshimura, V. J. Ferrans, M. S. Chernick, and R. G. Crystal. 1991. Expression of the cystic fibrosis transmembrane conductance regulator gene in the respiratory tract of normal individuals and individuals with cystic fibrosis. Proc. Natl. Acad. Sci. USA. 88:6565-6569.

20. Yoshimura, K., H. Nakamura, B. C. Trapnell, W. Dalemans, A. Pavirani, J.-P. Lecocq, and R. G. Crystal. 1991. The cystic fibrosis gene has a "housekeeping"-type promoter and is expressed at low levels in cells of epithelial origin. $J$. Biol. Chem. 266:9140-9144.

21. Trezise, A. E. O., and M. Buchwald. 1991. In vivo cell-specific expression of the cystic fibrosis transmembrane conductance regulator. Nature (Lond.). 353:434-437.

22. Breeze, R. G., and E. B. Wheeldon. 1977. The cells of the pulmonary airways. Am. Rev. Respir. Dis. 116:705-777.

23. Evans, M. J., and S. G. Shami. 1989. Lung cell kinetics. In Lung Cell Biology. C. Lenfant, and D. Massaro, editors. Marcel Dekker, Inc., New York. $1-36$.

24. Jeffery, P. K., and L. Reid. 1975. New observations of rat airway epithelium: a quantitative and electron microscopic study. J. Anat. 120:295-320.

25. Stratford-Perricaudet, L., D., I. Makeh, M. Perricaudet, and P. Briand. 1992. Widespread long-term gene transfer to mouse skeletal muscles and heart. $J$. Clin. Invest. 90:626-630.

26. Thimmappaya, B., C. Weinberger, R. J. Schneider, and T. Shenk. 1982. Adenovirus VAI RNA is required for efficient translation of viral mRNAs at late times after infection. Cell. 31:543-551.

27. Yamamoto, T., B. de Crombrugghe, and I. Pastan. 1980. Identification of a functional promoter in the long terminal repeat of Rous sarcoma virus. Cell. 22:787-797.

28. Kalderon, D., B. L. Roberts, W. D. Richardson, and A. E. Smith. 1984. A short amino acid sequence able to specify nuclear location. Cell. 39:499-509.

29. Price, J., D. Turner, and C. Cepko. 1987. Lineage analysis in the verte- brate nervous system by retrovirus-mediated gene transfer. Proc. Natl. Acad. Sci. USA. 84:156-160.

30. Gilardi, P., M. Courtney, A. Pavirani, and M. Perricaudet. 1990. Expression of human $\alpha 1$-antitrypsin using a recombinant adenovirus vector. FEBS (Fed. Eur. Biochem. Soc.) Lett. 267:60-62.

31. Graham, F. L., J. Smiley, W. C. Russell, and R. Nairn. 1977. Characteristics of a human cell line transformed by DNA from human adenovirus type $5 . J$. Gen. Virol. 36:59-74.

32. Graham, F. L., and A. J. Van Der Eb. 1973. A new technique for the assay of infectivity of human adenovirus 5 DNA. Virology. 52:456-467.

33. Rotman, B. 1961. Measurement of activity of single molecules of $\beta$-D-galactosidase. Proc. Natl. Acad. Sci. USA. 47:1981-1990.

34. Dannenberg, A. M., and M. Suga. 1981. Histochemical stains for macrophages in cell smears and tissue sections: $\beta$-galactosidase, acid phosphatase, nonspecific esterase, succinic dehydrogenase, and cytochrome oxidase. In Methods for Studying Mononuclear Phagocytes. D. O. Adams, M. J. Edelson, and H. S. Koren, editors. Academic Press, New York. 375-395.

35. Sanes, J. R., J. L. R. Rubenstein, and J.-F. Nicolas. 1986. Use of a recombinant retrovirus to study post-implantation cell lineage in mouse embryos. $E M B O$ (Eur. Mol. Biol. Organ.) J. 5:3133-3142.

36. Bolduc, P., and L. Reid. 1976. Mitotic index of the bronchial and alveolar lining of the normal rat lung. Am. Rev. Respir. Dis. 114:1121-1128.

37. Shorter, R. G., J. L. Titus, and M. B. Divertie. 1966. Cytodynamics in the respiratory tract of the rat. Thorax. 21:32-37.

38. Plopper, C. G. 1990. Structural methods for studying bronchiolar epithelial cells. In Models of Lung Disease. C. Lenfant, and J. Gil, editors. Marcel Dekker, Inc., New York. 537-555.

39. Ginsberg, H. S., R. L. Horswood, R. M. Chanock, and G. A. Prince. 1990 Role of early genes in pathogenesis of adenovirus pneumonia. Proc. Natl. Acad. Sci. USA. 87:6191-6195.

40. Jeffery, P. K., and L. Reid. 1977. Ultrastructure of airway epithelium and submucosal gland during development. In Development of the Lung. W. A. Hodson, editor. Marcel Dekker, Inc., New York. 87-134.

41. Jeffery, P. K. 1983. Morphologic features of airway surface epithelial cells and glands. Am. Rev. Respir. Dis. 128:S14-S20.

42. Ayers, M. M., and P. K. Jeffery. 1988. Proliferation and differentiation in mammalian airway epithelium. Eur. Respir. J. 1:58-80.

43. Evans, M. J., and P. C. Moller. 1991. Biology of airway basal cells. Exp. Lung Res. 17:513-531. 